\section{1-Aminocyclopropane Carboxylic Acid Shows Promise as a Chemical Thinner for Apple}

\author{
James R. Schupp ${ }^{1}$, Thomas M. Kon, and H. Edwin Winzeler \\ Department of Horticulture, Pennsylvania State University Fruit Research \\ and Extension Center, P.O. Box 330, Biglerville, PA 17307
}

Additional index words. ACC, agrichemicals, biennial bearing, chemical thinner, crop load, ethephon, flower initiation, fruit abscission, fruit thinning, Malus $\times$ domestica

\begin{abstract}
The objective of these studies was to evaluate the efficacy of several concentrations of 1-aminocyclopropane carboxylic acid (ACC) for thinning apple at the standard growth stage for chemical thinning timing and a late thinning growth stage. ACC was applied at concentrations of $0,100,300$, or $500 \mathrm{mg} \cdot \mathrm{L}^{-1}$ to 'Golden Delicious'/ Bud.9 apple trees at $10 \mathrm{~mm}$ or $20 \mathrm{~mm}$ fruit diameter. Treatments were applied to the point of drip to individual whole trees in a completely randomized design with five (2010) and six (2011) replications. When ACC was applied at $20 \mathrm{~mm}$, there was a linear dose relationship between concentration and fruit thinning in both years. ACC was ineffective at $10 \mathrm{~mm}$. The naturally occurring compound ACC shows potential for use as a reliable late chemical thinner for apple.
\end{abstract}

There is interest in developing new chemical thinners that are safe and naturally occurring. Existing thinners can cause phytotoxicity, pose hazards to beneficial and pollinating insects, and some are under review by regulatory agencies for possible withdrawal from legal use (Greene, 2002; McArtney, 2011).

Two frequently used post-bloom chemical thinners for apple, the synthetic cytokinin 6-benzyladenine and the synthetic auxin 1-napthaleneacetic acid, produce some level of thinning over a range of timing from petal fall up to 15- to 16-mm fruit diameter (Batjer et al., 1968; Byers, 2003; Donohoe, 1968; Greene, 2002). Sometimes it may be necessary to apply thinners later than is optimal for these compounds as a result of unfavorable weather during the optimal application window, uncertainty of the strength of initial fruit set, and/or because earlier attempts to thin have failed to adequately adjust the cropload.

Currently there are two registered compounds that are effective in the late thinning window (17- to 25-mm fruit diameter): (2-chloroethyl)-phosphonic acid (ethephon) and 1-napthyl(N)methyl carbamate (carbaryl). The ethylene-generating compound ethephon is a potent thinner that is therefore considered a risk to overthin (Greene, 2002), especially with ethephon-sensitive cultivars such as 'Golden Delicious' and 'Rome' (Byers,

\footnotetext{
Received for publication 16 Apr. 2012. Accepted for publication 7 July 2012

We thank Melanie Schupp, Rich Marini, Tara Auxt Baugher, Eric Anderson, and Celine Kuntz for their technical contributions and/or manuscript editing. Thanks to Valent BioSciences, Inc. for providing ACC for this research.

${ }^{1}$ To whom reprint requests should be addressed; e-mail jrs42@psu.edu.
}

2003). Carbaryl is considered a mild thinner and is most often used in a tank mix to boost the activity of other thinning chemistries. Sensitivity to chemical thinners ends when fruits reach $25 \mathrm{~mm}$ in diameter (Byers, 2003; Greene, 2002). It would be desirable to identify compounds with moderately strong thinning activity and a relatively low risk of excessive thinning for eventual registration and use as late thinners.

ACC is the precursor to ethylene (Adams and Yang, 1979). Several characteristics of ACC seem favorable for potential development as a plant bioregulator. ACC is a naturally occurring amino acid. The conversion of S-adenosyl methionine to ACC is the ratelimiting step in the ethylene biosynthesis pathway, and ACC is readily translocated in plants (Bradford and Yang, 1980). ACC is readily converted to ethylene by a wide variety of plant tissues (Cameron et al., 1979). Recent evidence suggests that foliar application of ACC has activity as an apple thinstudies was to evaluate the efficacy of several concentrations of ACC for thinning apple at the standard growth stage for chemical thinning timing, 10-mm fruit diameter, and a late thinning growth stage of 20-mm fruit diameter.

\section{Materials and Methods}

A block of mature vertical axis 'Golden Delicious'/Bud.9 apple trees growing at the Pennsylvania State Fruit Research and Extension Center, Biglerville, PA, at 1433 trees per hectare was selected. A factorial experiment was established with two growth stages and three concentrations of ACC with five (2010) or six (2011) replications in a completely random design. Treatments were applied on $30 \mathrm{Apr}$. or 14 May 2010 and on 11 or 20 May 2011; these dates correspond to 10- and ner (McArtney, 2011).The objective of these 20-mm fruit diameters in the respective year. ACC was applied at $0,100,300$, and $500 \mathrm{mg} \cdot \mathrm{L}^{-1}$ to individual trees to the point of drip using a $\mathrm{CO}_{2}$ pressure sprayer (Bellspray, Inc., Opelousas, LA) calibrated to deliver spray at $276 \mathrm{KPa}$ and fitted with a Teejet 8004 flat fan nozzle (Spraying Systems Inc., Wheaton, IL). In 2011, a spray of $300 \mathrm{mg} \cdot \mathrm{L}^{-1}$ ethephon [(2-chloroethyl)-phosphonic acid; Ethephon 2SL; Makhteshim-Agan of North America, Inc., Raleigh, NC] at $20 \mathrm{~mm}$ was included for comparison. A proprietary surfactant and buffering agent (LI-700; Crop Protection Services, Biglerville, PA) was added to all tanks at $0.12 \%$ (vol:vol) before mixing the active ingredients.

Before application, two branches per tree were selected and tagged. The number of flower clusters was counted, and at the end of June drop, persisting fruit were counted. Fruit set was extremely heavy in 2010 , so after fruit set counts, the control trees were handthinned to a uniform crop load of seven fruits/ $\mathrm{cm}^{2}$ of limb cross-sectional area (LCSA). Final fruit set of unthinned trees was moderate in 2011, so the controls were not handthinned in that year. Fruit set was expressed as the number of fruit per LCSA. At normal commercial harvest time in September, all fruit from each tree were harvested and individually weighed by an electronic weight sizer (Durand-Wayland, Lagrange, GA). Return bloom was determined by counting the number of blossom clusters on two limbs per tree at the pink stage of flower development and calculating the number of flower clusters per LCSA.

Data were analyzed using the PROC MIXED model in SAS (SAS Institute, Cary, NC). In all cases in which there were multiyear data, significant interactions between year and timing were found. Also, in all cases, significant timing and concentration interactions were found. Therefore, we analyzed years separately in the final models and also analyzed the timings separately.

\section{Results and Discussion}

In both 2010 and 2011, ACC application at the $20-\mathrm{mm}$ growth stage was effective at reducing fruit set and ineffective at $10 \mathrm{~mm}$ (Table 1). There was a linear dose response at $20 \mathrm{~mm}$ for reduction in yield and increase in fruit size. Fruit size distribution in 2010 was shifted to the larger size classes for trees treated with 300 or $500 \mathrm{mg} \cdot \mathrm{L}^{-1}$ at $20 \mathrm{~mm}$ (Fig. 1). These two treatments also increased return bloom. Fruitlet thinning response at $20 \mathrm{~mm}$ from ACC at $500 \mathrm{mg} \cdot \mathrm{L}^{-1}$ was similar to that of $300 \mathrm{mg} \cdot \mathrm{L}^{-1}$ ethephon (data not presented). This comparison was made because 'Golden Delicious' is easily overthinned with ethephon (Byers, 2003). It appears that there is a gradual dose response to ACC for this important cultivar that would facilitate a range of thinning options for the practitioner.

In 2011 application of ACC at both growth stages produced similar thinning dose responses to those in 2010 , resulting in reduced yield with increasing ACC concentration 
Table 1. Treatment means with application of 1-aminocyclopropane carboxylic acid concentration at two growth stages (10-mm size and 20-mm size) of fruit set, cropload, yield, yield efficiency, fruit size, and large fruit fraction of 'Golden Delicious' during the 2010 and 2011 growing seasons. ${ }^{\text {z }}$

\begin{tabular}{|c|c|c|c|c|}
\hline \multirow[b]{2}{*}{ Concn (ppm) } & \multicolumn{2}{|c|}{2010} & \multicolumn{2}{|c|}{2011} \\
\hline & $10 \mathrm{~mm}$ & $20 \mathrm{~mm}$ & $10 \mathrm{~mm}$ & $20 \mathrm{~mm}$ \\
\hline \multicolumn{5}{|c|}{-------Fruit set (no./LCSA)-------- } \\
\hline 0 & 15.8 & - & 11.7 & - \\
\hline 100 & 17.4 & 11.6 & 9.3 & 14.2 \\
\hline 300 & 13.1 & 10.6 & 8.1 & 7.6 \\
\hline 500 & 16.6 & 4.2 & 9.8 & 4.6 \\
\hline \multicolumn{5}{|l|}{ Significance } \\
\hline Linear & NS & 0.0001 & NS & 0.0003 \\
\hline Quadratic & NS & NS & NS & NS \\
\hline \multicolumn{5}{|c|}{--------Yield (kg/tree)-------- } \\
\hline 0 & 42.5 & - & 42.3 & - \\
\hline 100 & 45.6 & 42.5 & 34.1 & 38.9 \\
\hline 300 & 49.9 & 34.9 & 24.5 & 22.2 \\
\hline 500 & 42.0 & 24.5 & 28.9 & 24.8 \\
\hline \multicolumn{5}{|l|}{ Significance } \\
\hline Linear & NS & 0.0001 & 0.0077 & 0.0109 \\
\hline \multirow[t]{2}{*}{ Quadratic } & NS & NS & 0.0354 & 0.0343 \\
\hline & \multicolumn{3}{|c|}{---1 } & \\
\hline 0 & 127.3 & - & 161.9 & - \\
\hline 100 & 127.1 & 126.7 & 189.3 & 171.9 \\
\hline 300 & 129.5 & 170.4 & 196.6 & 194.7 \\
\hline 500 & 122.1 & 179.6 & 181.5 & 208.2 \\
\hline \multicolumn{5}{|l|}{ Significance } \\
\hline Linear & NS & 0.0109 & 0.0010 & 0.0013 \\
\hline \multirow[t]{2}{*}{ Quadratic } & NS & 0.0343 & 0.0024 & NS \\
\hline & \multicolumn{3}{|c|}{---1no./TCSA)y ${ }^{\mathrm{y}}-\mathrm{-}$} & \\
\hline 0 & & - & 9.07 & - \\
\hline 100 & - & - & 6.38 & 7.12 \\
\hline 300 & - & - & 4.46 & 3.72 \\
\hline 500 & - & - & 6.14 & 2.10 \\
\hline \multicolumn{5}{|l|}{ Significance } \\
\hline Linear & - & - & 0.0005 & 0.0185 \\
\hline \multirow[t]{2}{*}{ Quadratic } & - & - & 0.0025 & NS \\
\hline & \multicolumn{3}{|c|}{------Yield efficiency $(\mathrm{kg} / T C S A)^{\mathrm{y}}$} & \\
\hline 0 & & - & 1.46 & - \\
\hline 100 & - & - & 1.20 & 1.21 \\
\hline 300 & - & - & 0.86 & 0.72 \\
\hline 500 & - & - & 1.11 & 0.45 \\
\hline Significance & & - & & \\
\hline Linear & - & - & 0.0108 & 0.0004 \\
\hline \multirow[t]{2}{*}{ Quadratic } & - & - & 0.0302 & NS \\
\hline & fruit fro & f total yiel & han $76 \mathrm{~mm}$ & \\
\hline 0 & 10.6 & - & 36.4 & - \\
\hline 100 & 8.7 & 8.6 & 63.4 & 46.8 \\
\hline 300 & 7.8 & 38.1 & 71.2 & 69.9 \\
\hline 500 & 6.2 & 53.3 & 58.7 & 82.2 \\
\hline \multicolumn{5}{|l|}{ Significance } \\
\hline Linear & NS & 0.0001 & 0.0003 & 0.0005 \\
\hline \multirow[t]{2}{*}{ Quadratic } & NS & NS & 0.0012 & NS \\
\hline & $-----R$ & n (no. clus & ----- & \\
\hline 0 & 6.23 & - & 12.4 & - \\
\hline 100 & 6.40 & 5.55 & 12.1 & 9.27 \\
\hline 300 & 7.49 & 17.7 & 16.1 & 20.9 \\
\hline 500 & 5.65 & 19.1 & 17.1 & 20.8 \\
\hline Significance & & & & \\
\hline Linear & NS & 0.0010 & 0.0373 & 0.0002 \\
\hline Quadratic & NS & NS & NS & NS \\
\hline
\end{tabular}

${ }^{\mathrm{z}}$ Treatment means of five (2010) or six (2011) replicates.

${ }^{y}$ Measurements of cropload and yield efficiency were not made in 2010.

LCSA = limb cross-sectional area; NS = nonsignificant; TCSA = trunk cross-sectional area.

when applied at $20 \mathrm{~mm}$ (Table 1). Application of ACC at $20 \mathrm{~mm}$ resulted in a strong and very highly significant negative relationship between ACC concentration and crop density. Although blossom cluster counts show that the potential crop was supraoptimal in 2011 (an overall average 16 clusters $/ \mathrm{cm}^{2}$ LCSA with all plot averages above 14 clusters $/ \mathrm{cm}^{2}$ LCSA), the cropload after June drop on untreated control trees was nearly optimal, suggesting that a carbon deficit caused by environmental factors alone was adequate to adjust cropload in this orchard in 2011 (Lakso et al., 2001). Consequently, any additional thinning resulting from effective treatments reduced fruit set below the optimal level. Although increasing concentrations of ACC at $20 \mathrm{~mm}$ increased the proportion of large fruit (Fig. 1), because ACC at either timing reduced crop below the optimal cropload, there was only a small gain in the yield of large fruit to compensate for the loss of total yield in 2011.

Daily light and temperature data were used for calculation of the MaluSim carbon balance model (Lakso et al., 2001), which showed a period of carbohydrate surplus immediately after the $10-\mathrm{mm}$ application in 2010 and a period of moderate stress after the 20-mm application (Fig. 2). MaluSim calculations showed several periods of strong carbon balance deficit in 2011 , resulting from high temperatures and low light conditions during the natural fruit set period. One of these stress periods coincided with the $10-\mathrm{mm}$ treatment. A severe deficit also occurred shortly after the $20-\mathrm{mm}$ treatment was applied.

No symptoms of phytotoxicity were observed in either year (data not presented) McArtney (2011) observed some yellowing of 'GoldRush' leaves in 1 of 2 years when dilute application was made to individual spurs with a spray bottle but not when sprays were applied to 'Pink Lady' trees by airblast sprayer. Additional study is needed to determine if certain cultivars are more sensitive, what the maximum safe concentration is for such cultivars, and to optimize spray application technology for ACC.

ACC had efficacy at $20 \mathrm{~mm}$ in both years of our study. McArtney (2011) reported that although 'Pink Lady' trees had no thinning response to ACC, there was elevated ethylene generated in detached spurs by $10 \mathrm{~mm}$ and earlier treatments, but ethylene evolution was muted when ACC was applied at $20 \mathrm{~mm}$. Ethephon is effective as a blossom thinner (Jones, 1990) but is ineffective $7 \mathrm{~d}$ after bloom (Bound et al., 1993). Ethephon efficacy as a post-bloom thinner redevelops as fruits reach $16 \mathrm{~mm}$ in diameter (Marini, 1996). Our data from both years show a similar relationship between fruit growth stage and sensitivity to ACC.

The dose response at 20-mm fruit diameter was strong and linear in both years. This suggests that there may be a considerable range of appropriate rates of ACC for apple thinning. If true, this would allow concentration adjustments to year-to-year variations in fruit set and to the weather forecast at the time of application. The apparent wide range in ACC dose response is especially noteworthy because 'Golden Delicious' is highly sensitive to ethephon, which restricts the commercial application of ethephon to a low rate on this cultivar (Byers, 2003). McArtney (2011) also noted a linear dose response in fruit set of individual spurs of 'GoldRush' from 50 to $200 \mathrm{mg} \cdot \mathrm{L}^{-1} \mathrm{ACC}$, 

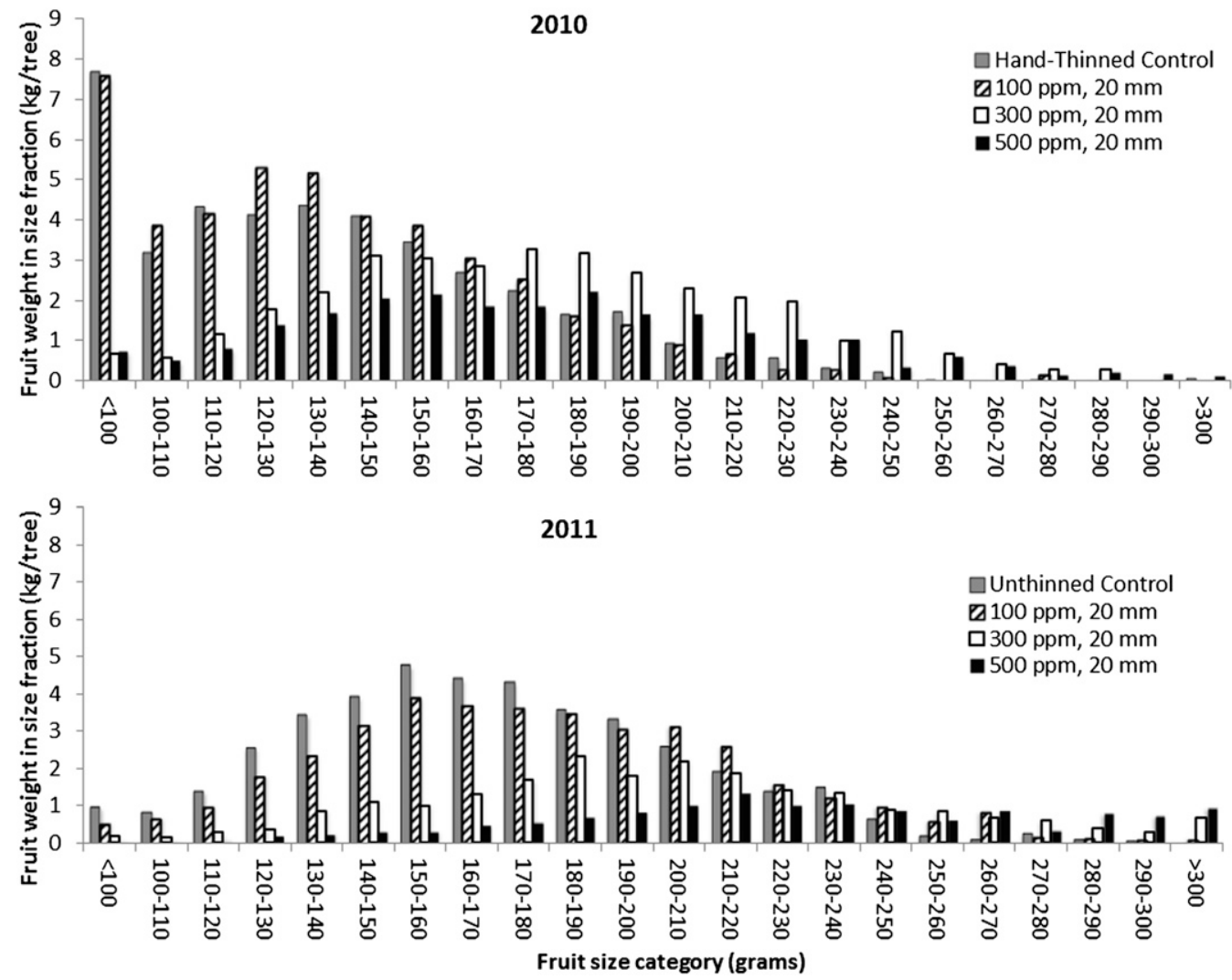

Fig. 1. Fruit size distribution of 'Golden Delicious' sprayed with three concentrations of 1-aminocyclopropane carboxylic acid at the 20-mm fruit diameter growth stage.

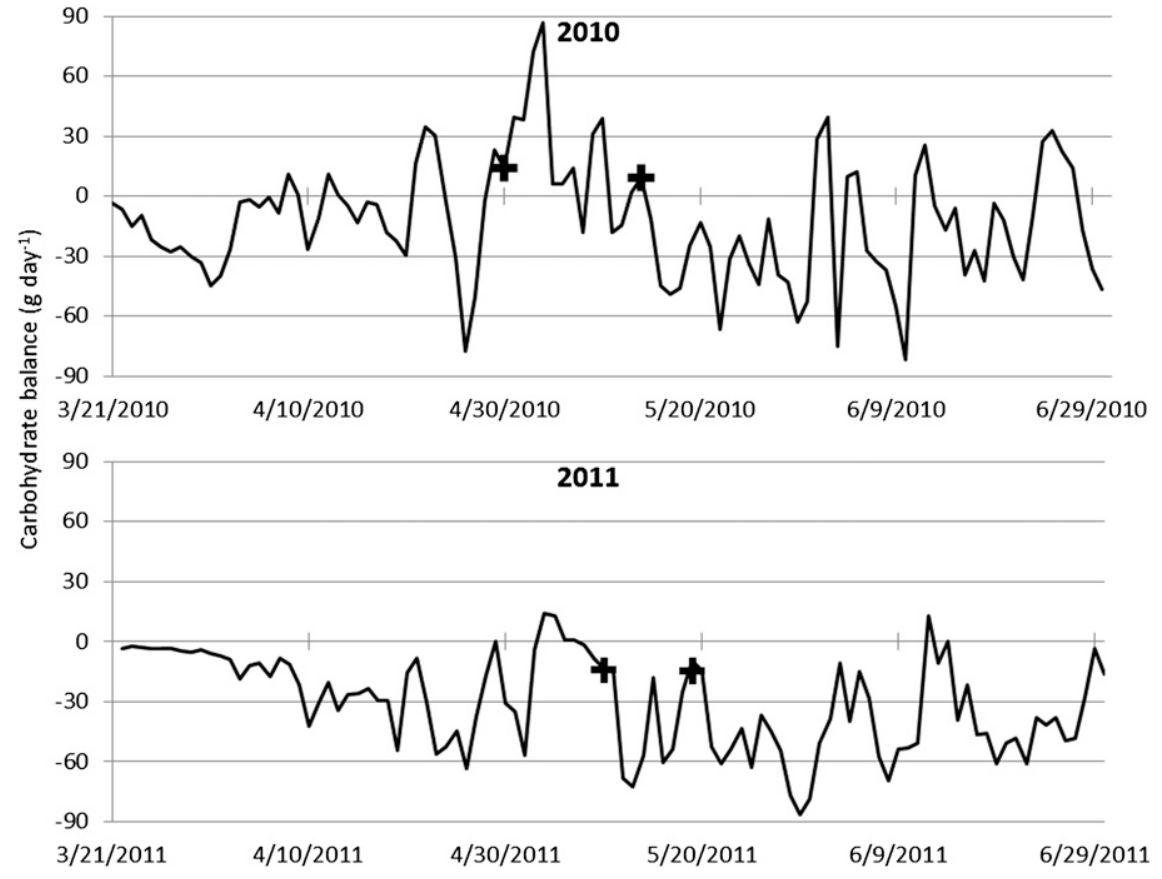

Fig. 2. MaluSim carbon balance model for 2010 and 2011 thinning seasons, Biglerville, PA. Crosses indicate dates of application of 1-aminocyclopropane carboxylic acid at 10-mm and 20-mm fruit growth stages, respectively.

although whole tree sprays of ACC to 'Pink Lady' were ineffective at full bloom, $10 \mathrm{~mm}$, or $20 \mathrm{~mm}$. ACC was consistently effective when used at 300 or $500 \mathrm{mg} \cdot \mathrm{L}^{-1}$ in our studies at the 20 -mm timing. Our results, taken in consideration with those of McArtney (2011), suggest that concentrations between 200 and $500 \mathrm{mg} \cdot \mathrm{L}^{-1}$ should be investigated further, focusing on the $20-\mathrm{mm}$ timing, and that trials should be conducted to compare cultivar sensitivity to ACC. The observed rate responses to $\mathrm{ACC}$ concentration occurred both years under hot temperatures, a condition under which overthinning with ethephon has been observed (Jones and Koen, 1985).

Our studies show that ACC has potential for development as an effective late chemical thinner for apple.

\section{Literature Cited}

Adams, D.O. and S.F. Yang. 1979. Ethylene biosynthesis: Identification of 1-aminocyclopropane1-carboxylic acid as an intermediate in the conversion of methionine to ethylene. Proc. Natl. Acad. Sci. USA 76:170-174.

Batjer, L.P., C.G. Forshey, and M.B. Hoffman. 1968. Effectiveness of thinning sprays as related to fruit size at time of spray application. Proc. Amer. Soc. Hort. Sci. 92: $50-54$.

Bound, S.A., K.M. Jones, M.J. Oakford, and M. Tichon. 1993. Assessing the interactive effects between cytolin and ethephon on cropping red delicious. J. Hort. Sci. 68:209-213.

Bradford, K.J. and S.F. Yang. 1980. Xylem transport of 1-aminocyclopropane-1-carboxylic acid, an ethylene precursor, in waterlogged tomato plants. Plant Physiol. 65:322-326.

Byers, R.E. 2003. Flower and fruit thinning and vegetative: Fruiting balance, p. 409-436. In: Ferree, D.C. and I.J. Warrington (eds.). Apples: Botany, production and uses. CAB International. Cameron, A.C., C.A.L. Fenton, Y. Yu, D.O. Adams, and S.F. Yang. 1979. Increased production of 
ethylene by plant tissues treated with 1-aminocyclopropane-1-carboxylic acid. HortScience 14:178-180.

Donohoe, C.W. 1968. The relationship of date of application and size of fruit to the effectiveness of NAA for thinning apples. Proc. Amer. Soc. Hort. Sci. 92:55-62.

Greene, D.W. 2002. Chemicals, timing, and environmental factors involved in thinner efficacy on apple. HortScience 37:477-481.
Jones, K.M. 1990. Thinning 'Red Fuji' apples using ethephon at two timings. J. Hort. Sci. 65:381-384.

Jones, K.M. and T.B. Koen. 1985. Temperature effects on ethephon thinning of apples. J. Hort. Sci. 60:21-24.

Lakso, A.N., M.D. White, and D.S. Tustin. 2001. Simulation modeling of the effects of short and long-term climatic variations on carbon balance of apple trees. Acta Hort. 557:473-480.
Marini, R.P. 1996. Chemically thinning spur 'Delicious' apples with carbaryl, NAA, and ethephon at various stages of fruit development. HortTechnology 6:241-246.

McArtney, S.J. 2011. Effects of 1-aminocyclopropane carboxylic acid on the rate of ethylene release from detached fruiting spurs and on fruit abscission in apple. J. Hort. Sci. Biotechnol. 86:640-644. 